\title{
An assessment of Sumatran elephant presences (Elephas maximus sumatranus) in Kotaagung Utara (Lampung, Indonesia) as a potential tourism attraction
}

\author{
AGUS SETIAWAN ${ }^{1}$, DELLA TIARA MONIK ${ }^{1, \vartheta}$, YOB CHARLES ${ }^{1,3}$, ELLY LESTARI RUSTIATI $^{2}$, \\ YANYAN RUCIYANSAH ${ }^{4}$, ZUFALDI ANWAR $^{5}$ \\ ${ }^{1}$ Departement of Environmental Science, Postgraduate Program, Universitas Lampung. Jl. Prof. Dr. Sumantri Brojonegoro No. 1 Bandar Lampung, \\ Lampung 35141, Indonesia. Tel.: +62-271-783682, "email: dellatiaraaa@gmail.com \\ ${ }^{2}$ Program of Conservation Biology, Department of Biology, Faculty of Mathematics and Natural Sciences, Universitas Lampung. Jl. Prof. Dr. Sumantri \\ Brojonegoro No. 1 Bandar Lampung, Lampung 35141, Indonesia \\ ${ }^{3}$ Forestry Department of Lampung Province. Jl. Zainal Abidin Pagar Alam, Bandar Lampung, Lampung 35144, Indonesia. Tel.: +62-271-703177 \\ ${ }^{4}$ World Wide Fund for Nature, Non-Government Organization, Lampung. Jl. Pulau Morotai, Jagabaya III, Bandar Lampung, Lampung 35132, Indonesia. \\ Tel.: +62-271-703949. \\ ${ }^{5}$ Rumah Kolaborasi, Non-Government Organization. Jl. Danau Singkarak No. 31-48, Bandar Lampung, Lampung 35122, Indonesia
}

Manuscript received: 27 September 2021. Revision accepted: 19 November 2021

\begin{abstract}
Setiawan A, Monik DT, Charles Y, Rustiati EL, Ruciyansah Y, Anwar Z. 2021. An assessment of Sumatran elephant presences (Elephas maximus sumatranus) in Kotaagung Utara (Lampung, Indonesia) as a potential tourism attraction. Biodiversitas 22: 53975407. Kesatuan Pengelolaan Hutan (KPH) Kotaagung Utara is a region of approximately 56.02 ha, consisting of $8.82 \%$ forest cover and $91.18 \%$ non-forest cover. This region has a high diversity of flora and fauna and has potential as a tourist destination with various and unique biophysical attractions. One of the special features of this location is the presence of Sumatran elephants [Elephas maximus sumatranus (Temminck, 1847)]. Wild elephants in KPH are a tourism potential that can be developed to become a tourism attraction. The objectives of this research were to find out the elephant home ranges and the right window of time to observe the Sumatran elephants and assess safety, security, and convenience considerations for visitors to observe wild elephants. The method used in the research was an observation, and the results were qualitative data. The data collection's elephants movement through the use of GPS Collar from 2017-2020. The study identified that there are 16 wild elephants known as the Bunga group. The elephants can be observed from 7:30 to 12:00 am or 3:00 to 6:00 pm, with a duration of 3 hours per day. Steps can be taken to increase visitor's safety, security and convenience with the building of a treehouse, evacuation route, use of binoculars, and Personal Protective Equipment (PPE).
\end{abstract}

Keywords: Ecotourism, KPH Kotaagung Utara, tourism object, visitors

Abbreviation: Gapoktan: Gabungan Kelompok Tani Hutan; HKm: Hutan Kemasyarakatan; IUPA: Izin Usaha Pemanfaatan Alam; KHL: Kawasan Hutan Lindung; KPH: Kesatuan Pengelolaan Hutan; KPHL: Kesatuan Pengelolaan Hutan Lindung; PPE: Personal Protective Equipment; WWF: World Wide Fund for Nature

\section{INTRODUCTION}

Forest resources and forest areas must be managed and utilized sustainably to meet the social, economic, cultural and spiritual needs of present and future generations (Amenu 2017). One of the management can be used as nature tourism. Nature tourism is a form of tourism experience that promotes beauty, uniqueness, and value of biodiversity and artificial nature. According to Saat et al. (2015), ecotourism is a model of developing nature tourism that brings the joy of appreciating nature's beauty while sustaining the well-being of local communities and includes elements of education and conservation. With ecotourism, there's an emphasis on having interpretive and educational materials to provide information for potential tourists visiting the tourism place. Potential tourists are usually defined as people or individuals who will travel to areas with tourist attractions to get new experiences. The tourism potential is supported and facilitated by the location of tourist destinations, which depends on the resources, facilities and services provided by local communities, businesses, and local government (Arida et al. 2017). Kesatuan Pengelolaan Hutan (KPH) Kotaagung Utara is a region that has a high diversity of flora and fauna and has potential as a tourist destination with various and unique biophysical attractions. It is the largest KPH in Lampung Province after KPH Batu Tegi. One of the unique aspects of this location is the Sumatran elephant's existence [Elephas maximus sumatranus (Temminck, 1847)].

The Sumatran elephant is the largest land mammal in Sumatra under the Order Proboscidea. According to the International Union for Conservation of Nature (IUCN), the Sumatran elephant is listed in the Red List of Threatened Species with the critically endangered category (Critically Endangered). In Indonesia, the Sumatran elephant has been protected since 1931 by the Wild Animals Protection Ordinance No. 134 and 226 since 1931. Furthermore, the 
protection of Sumatran elephants is strengthened by Government Regulation No. 7, established in 1999, under the Preservation of Plant and Animal Species and Regulation of the Minister of Environment and Forestry Number P.106/MenLHK/Setjen/Kum.1/12/2018. However, the elephant population continues to decrease.

In general, Sumatran elephants can be found at low swamps, tropical forests (open canopy), and up to an altitude of \pm 1.000 meters above sea level (Sitompul et al. 2013). In line with Febryano and Rusita (2018), the Sumatran elephants tend to live near the water resources and areas with adequate forage supplies. The availability of food will affect the behavior of the elephant itself. Based on Sari et al. (2016) behavior of animals can be categorized based on their daily activities, namely, active time, movement area, food hunting, communication behavior, and reproduction. The elephants live in the group for specific activities such as food hunting (Kurniadu et al. 2020). Additionally, these animals will continue exploring and expanding their home range, especially for foraging (Bahar et al. 2018). One of the methods used to examine the roaming area of wild elephants in $\mathrm{KPH}$ Kotaagung Utara is by mapping and observing.

Factors such as safety, security and convenience are essential for tourist destinations. Every tourism attraction requires some form of security and accessibility, including protection from environmental conditions, activities, and road access to these attractions. Furthermore, to tolerate all forms of disturbance that will occur to tourists, like a risk of contracting a disease or accident while in a tourist attraction. This is intended to avoid various possible accidents experienced by tourists, including preventing disease transmission from animals to tourists or vice versa. If a tourist attraction can provide a sense of security and comfort, tourists will not feel physically and financially disadvantaged. The existence of wild elephants in KPH Kotaagung Utara is a tourism potential that has not been utilized. The various effort is necessary to develop it as a tourism attraction. The area's development as a tourism attraction will help increase regional income, especially for the people around the room. Hence, this research aims to investigate the presence, roaming areas, and suitable time to search for wild elephants while and to acknowledge the need for safety, security, and convenience for visitors to observe the Sumatran elephants in $\mathrm{KPH}$ Kotaagung Utara, Lampung, Indonesia.

\section{MATERIALS AND METHODS}

\section{Research location}

The research was conducted in KPH Kotaagung Utara, Tanggamus Regency, Lampung Province, Indonesia which is in the protected area of Kawasan Hutan Lindung (KHL), especially on Register 31 Pematang Arahan (Figure 1). The research was conducted from February 2021 to March 2021. The equipment used was a camera and binoculars, ArcGIS app, and data were recorded via Microsoft Exel and questionnaire.

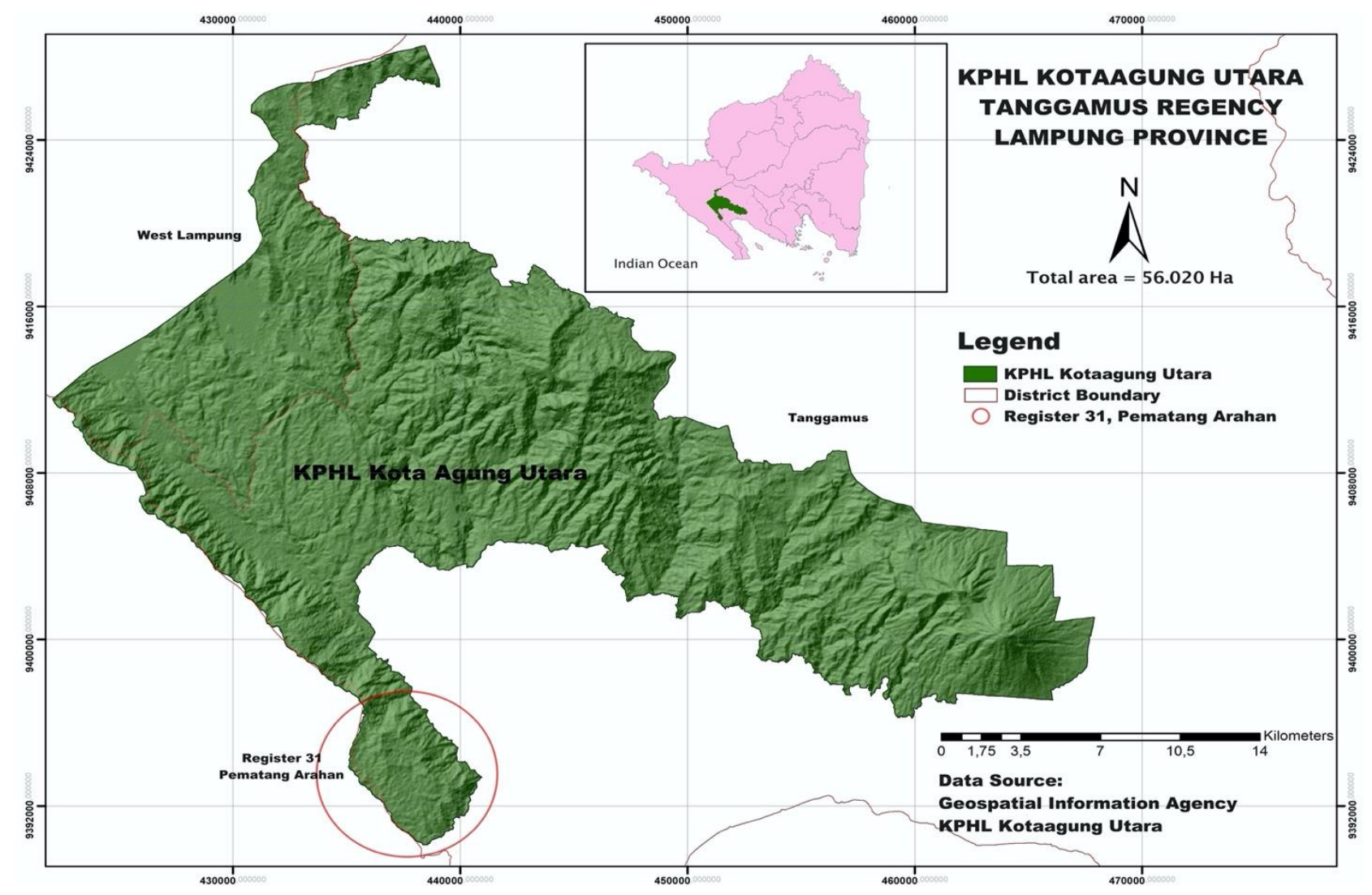

Figure 1. Research Location KPH Kotaagung Utara, Tanggamus Regency, Lampung Province, Indonesia 


\section{Procedures}

Data types and sources

The data were collected from two sources: primary and secondary data. Preliminary data were obtained by direct observation, meanwhile, secondary data were obtained from published literature, company websites, newspapers, and journals (Cerar et al. 2017). The data used in this research are presented in (Table 1).

\section{Data collection}

Register 31 Pematang Arahan is located in KPH Kotaagung Utara, Tanggamus Regency with a total area of 1505 ha. The elephant roaming area was obtained by mapping the range of Sumatran elephants in the Register 31 Pematang Arahan by overlaying elephant location obtained from a 4 year Global Positioning System (GPS) elephant collaring project by World Wide Fund for Nature Indonesia Southern Sumatra Program (2017-2020). The GPS is a modern satellite-based navigation system used to track locations. The GPS Collar is shaped like a belt and can be secured to an animal. The GPS Collar was used to monitor technology in recent decades, can improve scientific tools (Moßbrucker et al. 2016). The installation of a GPS Collar is intended to monitor the movement patterns and animal positions so that it can be used to mitigate conflicts between humans and Sumatran elephant wildlife. Then, primary and secondary data suitability obtained by direct observation of the Sumatran elephant's gathering times and points from treehouses to observe wild elephant's activities more closely at Register 31 Pematang Arahan, KPH Kotaagung Utara. The purpose of this observation can be to determine the place (safe and comfortable) and the right time for tourists to see elephants.

In-depth interviews were conducted with the society around KPH Kotaagung Utara, and respondents were obtained using a Snowball approach. Additionally, a structured interview was conducted with the Head of KPH Kotaagung Utara. The result from the structured interviews was used to determine the society's and the manager of KPH Kotagung Utara perceptions and opinions on the development planning of tourism attraction. Subsequently, another questionnaire was carried out on the society's perspective of elephants, the elephant's existence precisely, and the potential of the elephant's as a tourism attraction in KPH Kotaagung Utara.

\section{Data analysis}

The data were processed and analyzed data qualitatively. Qualitative analysis is a method used to solve problems that are not limited to data collection and organization but includes analysis and explanation of research results (Lester et al. 2020). The analysis is a process where the data is generated, then defined by existing problems. The data were collected by getting information and the results are described in words or sentences. The preparation can be implemented accurately according to the facts in the field, therefore, it indicates that the results were obtained regarding the planning of tourism objects in KPH Kotaagung Utara well-executed.

\section{RESULTS AND DISCUSSIONS}

\section{General condition of research field}

The KPH Model Kotaagung Utara (Unit X) was formed based on the Forestry Minister's Decree Republic of Indonesia No. SK.379/Menhut-II/2011 on July $18^{\text {th }}, 2011$ on Determination of Protected Forest Management Unit Area Model Kotaagung Utara (Unit X), located in Tanggamus Regency, Lampung Province. KPH Kotaagung Utara was established by the District Regulation of Tanggamus Regency Number 21 of 2011 concerning the Establishment of the Organization and Work Procedure of the KPH in Tanggamus Regency, Lampung Province. Geographically, KPH Kotaagung Utara in Tanggamus Regency is located at 104017'BT-104042'BT and 5010'LS-5030'LS, Lampung. The KPH Kotaagung Utara are divided into 3 main registers, namely Register 30 Gunung Tanggamus, KPH Register 31 Pematang Arahan, and also KHP Register 39 Kotaagung Utara which is part of Tanggamus District Forestry Services Management Area. Management blocks in KPH Kotaagung Utara consist of Core Blocks and Utilization Blocks with a total area of \pm 56.020 ha, divided into 217 plots consisting of 55 core plots and 162 utilization plots.

Tabel 1. Data types and sources

\begin{tabular}{ll}
\hline \multicolumn{1}{c}{ Data } & Data sources \\
\hline Tourist attraction coordinates & Observation \\
Landscape of the area & Observation \\
Potential tourist attraction & Observation and interview \\
The time and place elephants visit frequently & Observation, interview of Gapoktan, and GPS \\
& Collar is the equipment for monitoring the elephant's home range \\
Management plan for tourist attractions and tourism areas (safety, & Observation and interview \\
security and convenience) for visitors & \\
\hline
\end{tabular}




\section{Tourists attraction}

Areas that are unique, and value in the form of biodiversity, culture and man-made nature, which have the potential to be developed as an attraction for tourists. The unique attributes of the Kesatuan Pengelolaan Hutan Lindung (KPHL) Kotaagung Utara are Sumatran elephants, Rafflesia arnoldii, and waterfalls at the end of the water flow. In addition to seeing the Sumatran elephant, tourists can get to witness the Rafflesia sp. habitat. There are 13 types of Rafflesia flowers scattered on Sumatra, Java, and Kalimantan in Indonesia (Susatya 2011). Based on the observation done using GPS Collar since 2017-2020 in KPH Kotaagung Utara, the elephants are primarily present every year in the same month. By then, the opportunity to see the elephants in their nature is possible. Wild elephants are such a big attraction for tourists (Lo and Janta 2021; Miftahudin et al. 2021). Wildlife tourism provides an opportunity for tourists to interact with animals which will strengthen an emotional connection closely. It will provide the tourist with new experiences which will develop a pro-environmental behavior (Flower et al. 2021). In the research area, the elephants are periodically passed over the same path. There are 2 treehouses which are 120 $\mathrm{m}$ and $113 \mathrm{~m}$ apart from the elephant cross trail, which is being used to observe the elephants. The Royal Jozini website stated that the elephant must be followed at least 70-100 m away.

\section{Supporting factors}

In general, a tourist destination will provide new experiences to tourists in attractions that can be enjoyed. An outdoor area is provided for tourists to play in, which also includes education. Supporting aspects can influence the factors that attract tourists to travel. For example, tourists may want to take a vacation to relax, enjoy, and relieve boredom (Kusumaningrum and Wachyuni 2020). But the decision for a location to visit may be influenced by the facilities and attractions facilities and attractions offered by tourist destinations, so tourists may find them to see the exact location frequently (Koranti et al. 2018). The cool air temperature combined with the beautiful scenery is a supporting factor in KPH Kotaagung Utara. In addition, adequate facilities and infrastructure and a relatively beautiful and well-maintained location make some rare plants such as $R$. arnoldii and Sumatran elephants alive and still looking for food around this location.

\section{Behavior and roaming area (home range) of the Sumatran elephant (Elephas maximus sumatranus)}

There are 24 Sumatran elephants in Tanggamus, consisting of two groups: the Bunga group (16 elephants) and the Citra group (8 elephants). In line with Alpiadi et al. (2019), who stated that elephants behave in a matriarchal pattern or live in groups. The roaming areas of the two groups include KPH Kotaagung Utara and Bukit Barisan Selatan National Park (TNBBS), based on movement observed over 1 to 2 years. However, the Bunga group dominates the Kotaagung Utara KPH area. Meanwhile, the Citra group dominates the Pemerihan area
(TNBBS). The movement of each group is influenced by the season and the condition of their habitat, especially food and home range. The number of wild elephants in a group ranges from 2 to 50 be solitary (Larisha et al. 2016). Each group is led by an adult female, while the adult males tend to stay for a short period only to mate with several females. Male elephants born in the group once reaching sexual maturity will be forced to leave their mother's group and join other male groups. Meanwhile, old elephants will live with the new social network and establish a social hierarchy (Evans 2019).

The population of Sumatran elephants is decreasing from year to year (Qomariah et al. 2019). Collins (2018) states the most significant factor affecting the elephant population is shifts and changes in a habitat like the largescale conversion of forest to monoculture plantations. Habitat change in the transformation of primary forest land into agricultural and plantation areas is a fundamental problem for elephant-human conflicts (Mustafa et al. 2018). Ministry of Environment and Forestry in RTMPPGS recognized that to minimize elephant-human disputes, there is a need to optimize barrier management and encourage coexistence practices between humans and elephants. Local resources are mobilized to manage the conflict with elephants, including cooperation with village areas, such as education programs about elephants, capacity building of the team tasked with monitoring wild elephants, and monitoring programs for the sustainability of society's resources in the long term. The prevention executed by the community around the KPH Kotaagung Utara area does carry out mitigation activities to prevent wild elephants from entering their plantation areas by using batons. These efforts were quite successful in chasing away elephants and minimizing the occurrence of non-natural elephant deaths and human deaths due to conflict. However, knowledge of elephant roaming is essential for humans. The range of humans is undoubtedly higher than elephants globally, and spatial planning is vital to reduce conflicts between humans and elephants (Sukmantoro et al. 2019).

Another prevention way to minimize conflicts with elephants was to observe the roaming area, pathways, and distribution of elephants in a location. World Wide Fund for Nature (WWF) and KPH Kotaagung Utara were tracking elephants using GPS Collar to monitor the location of the elephant groups and studied the movement patterns and the habitat range of elephants (Matthews et al. 2013). Traditionally, the home range is defined as the total area used by animals group to carry out their activities for a specific period (Fauvelle et al. 2017).

By looking at the path each group chooses during roaming, the study can identify home range restrictions. For example, based on the results of observations in 20172020 conducted by WWF and KPH Kotaagung Utara using a GPS Collar, the home range of two groups of wild elephants in Tanggamus covers the area of Register 31, Pematang Arahan (Figure 2). However, the main home range is in the Sido Makmur III, Murah Rezeki I, Mandiri Jaya, and Block Lindung II. 


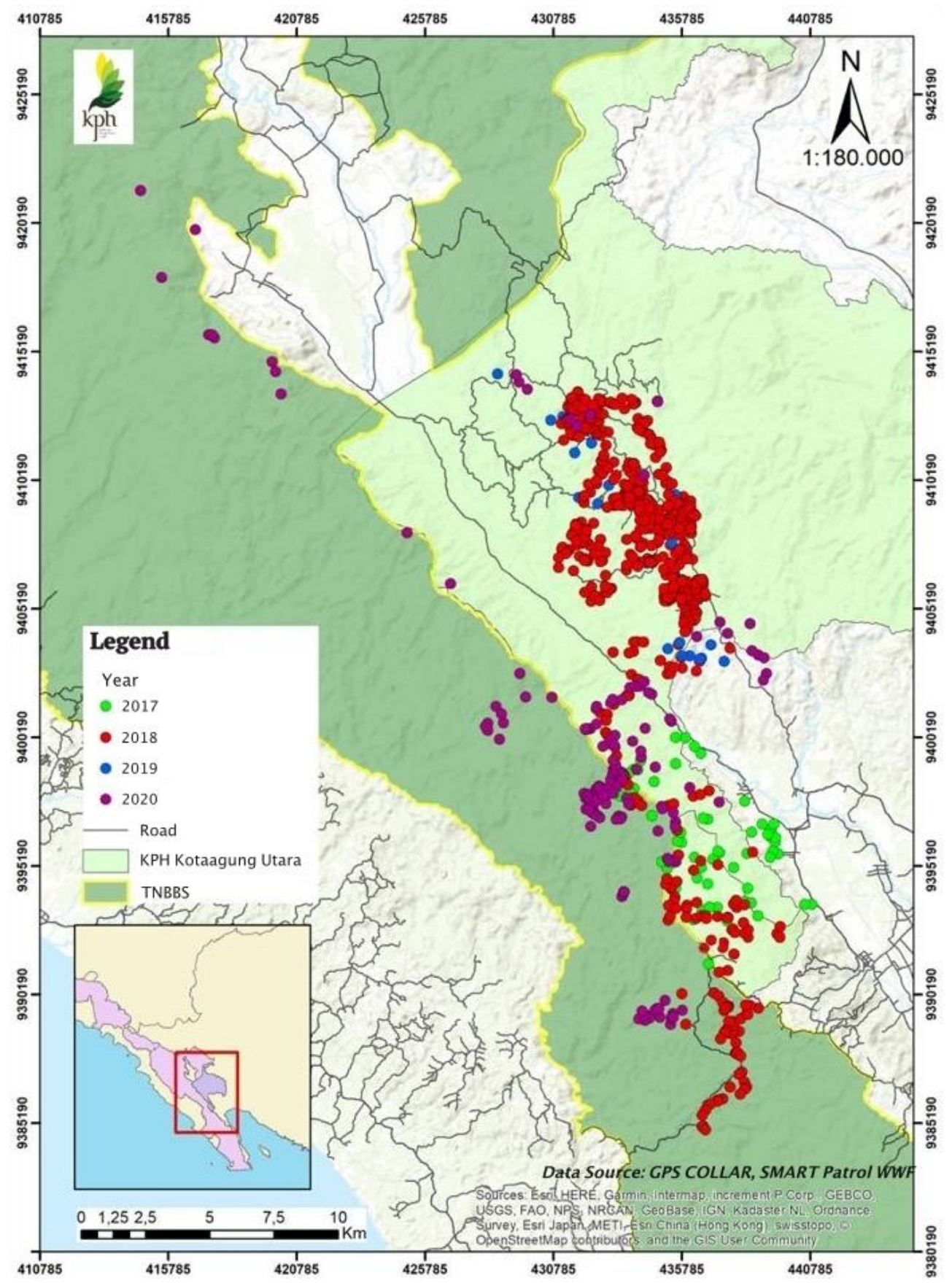

Figure 2. Distribution map of wild elephants (Bunga group) in Tanggamus Regency, Lampung Province, Indonesia for 2017-2020

The elephant food sources in each area are the main factor influencing the roaming activity of the wild elephant groups in KPH Kotaagung Utara. The number of plant species that grow under trees is few because forest vegetation composition has reached a climax. Thus the elephants rarely pass through such areas. This observation is supported by Dormann et al. (2020), who asserted that if the primary forest has reached the climax stage of succession, plant species diversity and abundance at the forest floor are relatively low. Another study speculates that high canopy forests may protect them from sunbeam (Mills et al. 2018). Furthermore, according to Songer et al.
(2012), the elephant's carrying capacity and food supply are reduced due to forest conversion effects. As a result, Sumatran elephants have to move away from forest areas to meet their needs. Other factors that may influence elephant movement, such as the need for safe locations to carry out daily activities: rest, communicating, and dressing up, are elephant behaviors to defend themselves from threats. The gift of nature in the forest is deserved to be guarded, and mother nature needs you to keep an eye out for her (Basappanavar 2021). If the environment and surroundings are not safe, the elephant will sleep standing up (Gravett et al. 2017). 
According to Posta (2011) elephants spend approximately 16 hours a day eating and are more active at night. Elephants were supplied as much as $250 \mathrm{~kg}$ of food per day (Berliani et al. 2018). The dominant plant species in the Sido Makmur III, Murah Rezeki I, Mandiri Jaya, and Block Lindung II areas are kans grass (Saccharum spontaneum), weeds (Imperata cylindrica), robusta coffee (Coffea canephora), Arabian coffee (Coffea arabica), gamal (Gliricidia maculata), dadap (Erythrina variegate), Java palisander (Dalbergia latifolia), fern palm (Cycas rumphii), sengon buto (Enterolobium cyclocarpum), rambutan (Nephelium lappaceum), and mangosteen (Garcinia mangostana). Clegg and O'Connor (2017) found that food chosen by elephants consists of grass, shrubs, foliage, bark, as well as hydrophyte, and fruit. The profitability of available food is determined by environment and time too. Sugiyanto et al. (2017) also revealed that elephants have foraging strategies when consuming grass and leaves in the dry and wet seasons. Elephants will choose fresh grass in the wet season because it contains carbohydrates and low fiber content (lignohemicellulose). Meanwhile, in the dry season, elephants prefer leaves containing high protein content, like (8-10\% Malvaceae and 10 to $20 \%$ Leguminoceae) (Singh 2019). The images were taken by the World Wide Fund for Nature Indonesia Southern Sumatra Program team (Figure 3).

Sido Makmur III, Murah Rezeki I, Mandiri Jaya, and Block Lindung II sites are areas where a large river flows, it can be seen in (Figure 4). Elephants depend on water, so in the afternoon, elephants will usually look for water sources to drink, bath, wallow, and of course, with good quality like water $\mathrm{pH}$, conductivity and total dissolved solids (Ndlovu et al. 2018). This observation is supported by Yanti et al. (2017), who suggested that elephants look for water sources to cool their bodies from the hot sun and repel insects that stick to their bodies.

An elephant needs 200-250 liters of drinking water/day (Sukoco 2012). Overall, vegetation and slope had the most significant impact on elephants (Wilson et al. 2021). The elephant's water and food supplies are influenced by physical environmental habitat factors, such as climate and soil. Changes in a habitat can disrupt the normal functioning of all existing biological systems. A suitable habitat will affect and determine the level of animal welfare, both its reproductive ability and resistance to disease (Capucchio et al. 2019). The habitat is deemed suitable if there are sufficient water and food supply for elephants. According to Kuncoro et al. (2017), elephants are susceptible to ectoparasite infections caused by flies in dirty rivers. Ectoparasites are parasites that live on the body surface of the host. The ectoparasites' disorder may manifest into various medical conditions, such as irritation, itching, inflammation, scabies, myiasis, various allergic and others. These symptoms effects an inconvenience caused and anxiety that may interfere the elephant's activity (Rizwar et al. 2017). The thing that elephants do to keep their metabolism balanced is by saltlicks (Sitienei et al. 2012). Mineral salts such as calcium, magnesium and potassium contained in the soil or cliffs taken by the elephant's trunk (Sach et al. 2019) are deemed helpful for elephants to help strengthen their bones, teeth, and tusks.

\section{Safety, security and convenience factors (Elephas maximus sumatranus)}

The ecotourism sector was suggested as a form of activity that can generate income for sustainable development without sacrificing the environment and benefit the next generation. However, maintaining a tourist attraction that is always visited by tourists and is sustainable may require special attention. Tourism attractions need a security guarantee, including safe environmental conditions, opportunities to be involved in social activities, and transportation access to the destination to tolerate any disturbance to tourists, such as the risk of contracting a disease or accidents while in a tourist attraction. This is very important to note, otherwise, it will be challenging to become a tourist attraction (Kirom et al. 2018). Tourist's convenience and safety are of priority, as they want to relax without worrying during their visits to a tourist attraction for a certain amount of time. Tourists are not willing to travel to an area if the region is involved in a conflict, war, or natural disaster. For this reason, a preparation plan is needed, both in terms of the destination's image and physical assets (Rossello et al. 2020). KPH Kotaagung Utara created the treehouse to observe wild elephant's activities more closely (Figure 5).

The KPH Kotaagung Utara built tree houses to observe wild elephant's activities more closely (Figure 5). The $\mathrm{KPH}$ Kotaagung Utara has two treehouses of different sizes. The treehouse (A), located $1.1 \mathrm{~km}$ from the Main Door/Rhino Camp, is a size $2.5 \mathrm{~m} \times 2 \mathrm{~m}$, built at the height of $12 \mathrm{~m}$. Meanwhile, the treehouse (A), located $1.8 \mathrm{~km}$ from the Main Door/Rhino Camp, has a size of $2.2 \mathrm{~m} \mathrm{x} 2 \mathrm{~m}$ and is built at the height of $14 \mathrm{~m}$. The two treehouses can fit 4-5 people. The construction of a treehouse is a unique concept, and the results were in different sizes. When building treehouses for observing elephants, essential considerations include determining the right location to face (towards the elephant's roaming area), safe geographical location, and selecting a solid tree as the building pillar. An ideal tree used as a building pillar should have solid trunks and branches, deep and strong roots, and no signs of parasites or disease that could weaken the tree. Other considerations include minimizing threats caused by other factors, such as natural factors, the environment, economic activity factors, and road access factors.

The purpose of building a treehouse in KPH Kotaagung Utara was to allow officers to observe elephants closely. However, the innovative use of treehouses can help attract tourists who want to see elephants directly. During the observation, the society and field forest ranger confirmed that they felt more secure and comfortable viewing elephants in the tree houses. This finding is in line with Maryone's (2015), which states that the purpose of building a treehouse is to avoid wildlife. Therefore, treehouses can be innovated and used for the planning and development of tourism attractions in KPH Kotaagung Utara. 


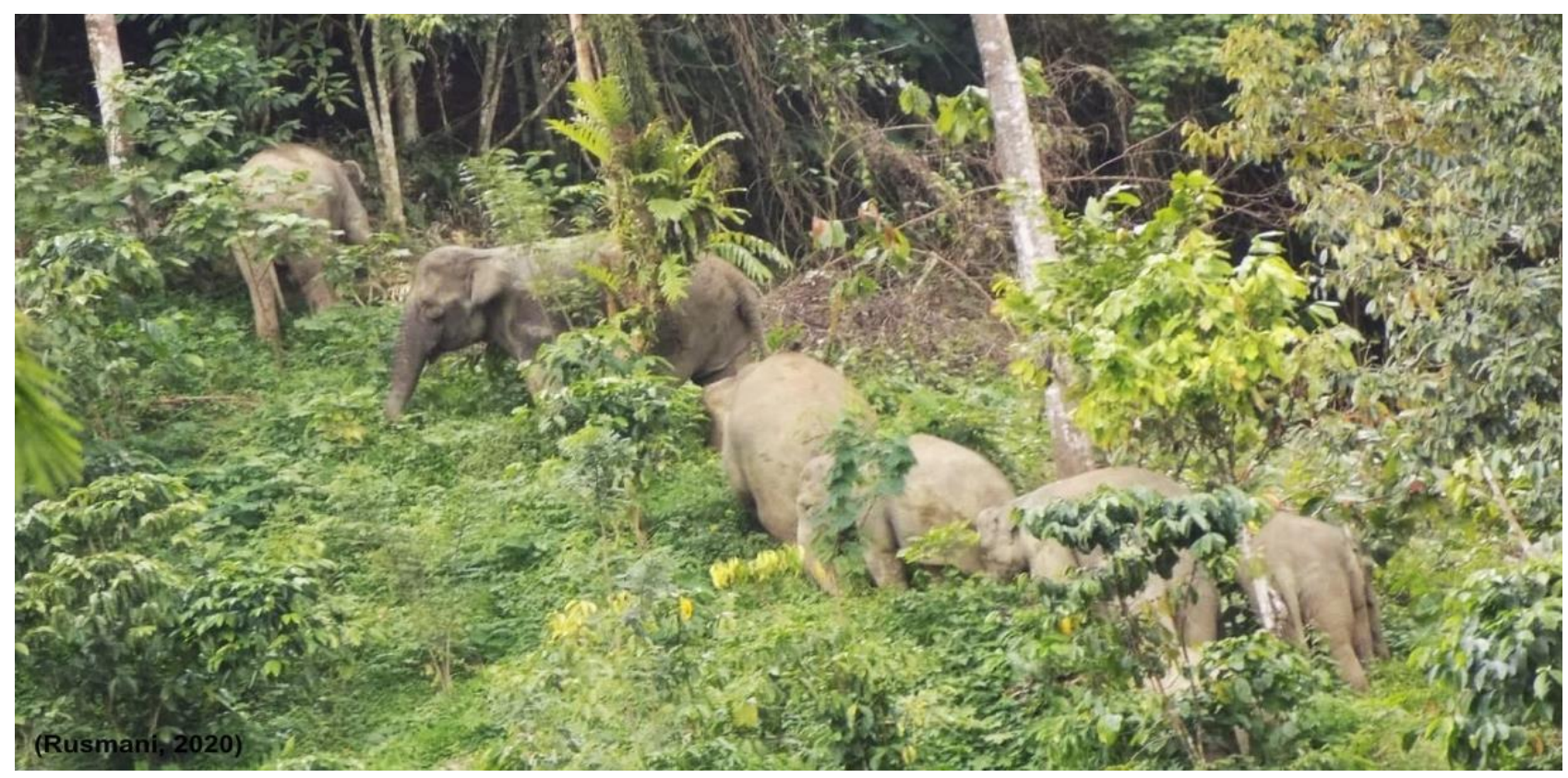

Figure 3. A wild elephants (Bunga) group were looking for food in KPH Kotaagung Utara, Tanggamus Regency, Lampung Province, Indonesia (Photo: Rusmani 2020)

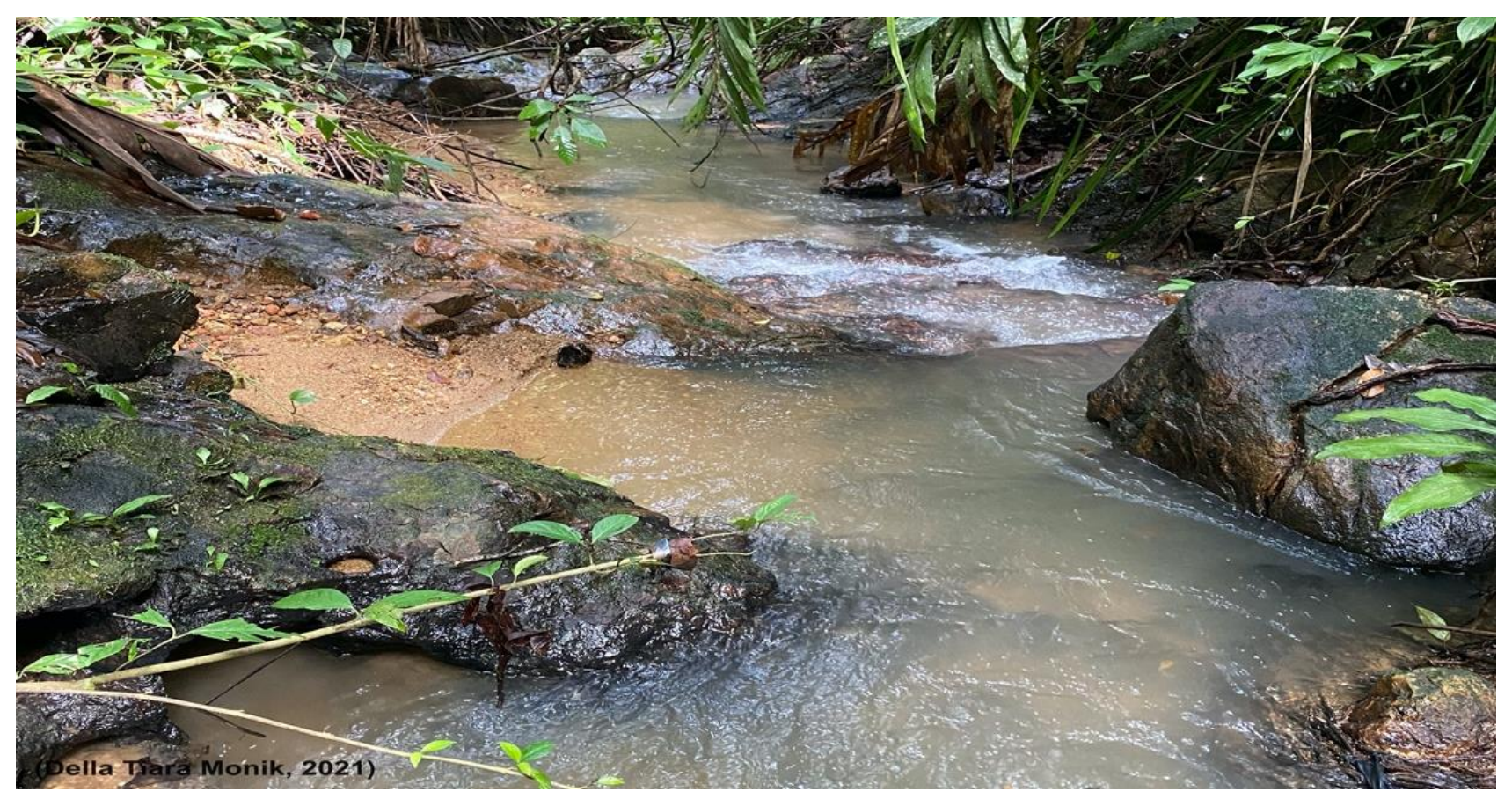

Figure 4. Block Lindung II, Register 31 Pematang Arahan, KPH Kotaagung Utara, Tanggamus Regency, Lampung Province, Indonesia (Photo: Della Tiara Monik 2021) 

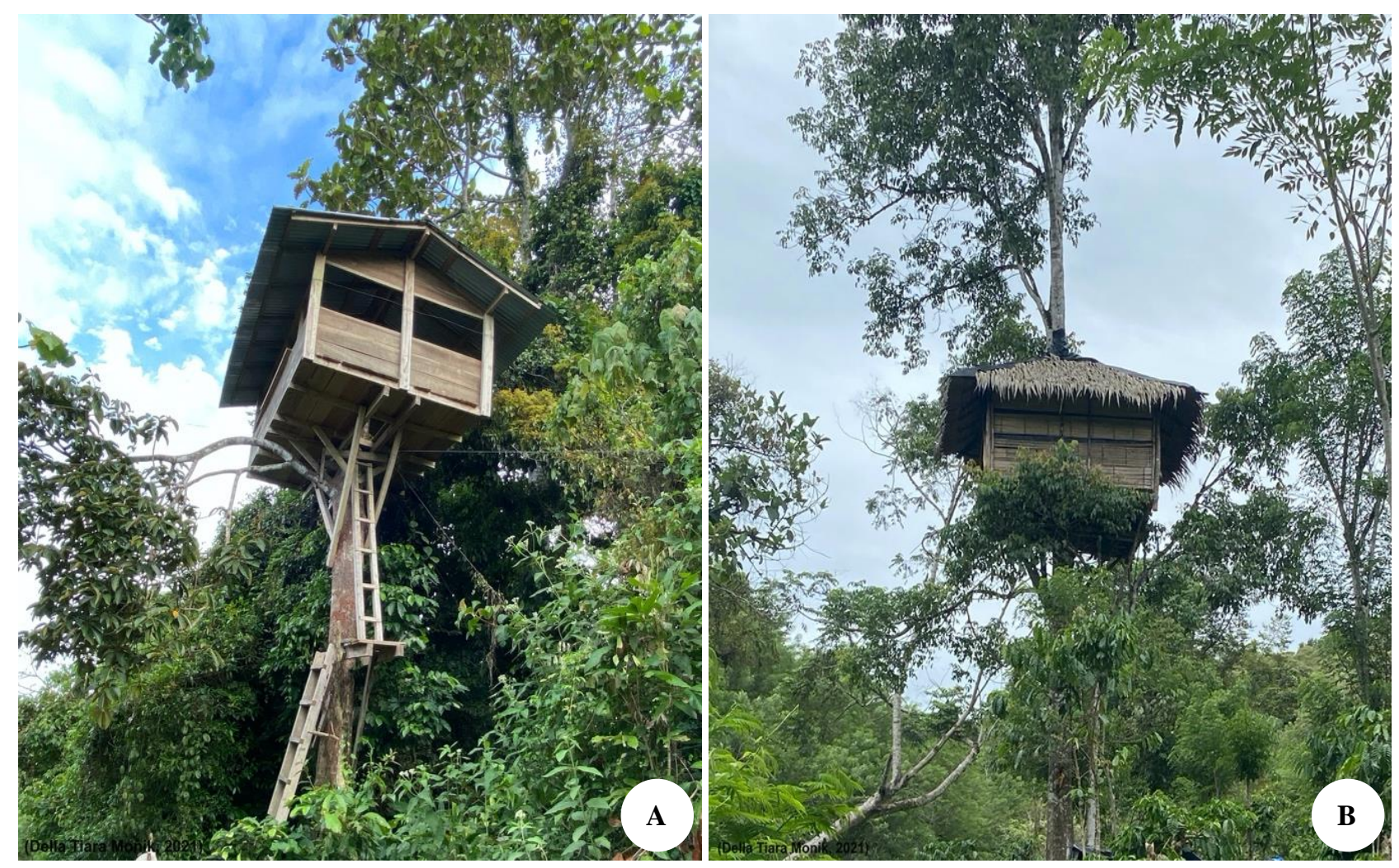

Figure 5. A. Treehouse (1) $120 \mathrm{~m}$ from the elephant cross trail (Photo: Della Tiara Monik 2021); B. Treehouse (2) $113 \mathrm{~m}$ from the elephant cross trail (Photo: Della Tiara Monik 2021)

Figure 4 shows that the elephant crossing area coincides with the river flows, especially in Mandiri Jaya and Block Lindung II. In the Block Lindung II area, there is a small waterfall and the Tetrastigma spp. plant is the $R$. arnoldii flower host. Tetrastigma spp can thrive in Mandiri Jaya and Block Lindung II compared to other areas. This is based on the availability of nutrients and supportive biotic and abiotic environmental conditions, such as temperatures of $25-29^{\circ} \mathrm{C}, \pm 7 \mathrm{~m}$ from water sources, and surrounded by animal pollinators (Diptera) that Tetrastigma spp. can survive and become a healthy flower host for $R$. arnoldii. Using complex carrying capacity, Mandiri Jaya and Block Lindung II areas can be used as a tourist attraction, including the elephant crossing, $R$. arnoldii and small waterfall, and it can be seen in (Figure 6).

Rafflesia arnoldii's existence and a small waterfall in the Block Lindung II area are valuable for tourists who want to see the Sumatran Elephant at KPH Kotaagung Utara. A proper distance and access to tourism objects will make it easier for tourists to visit. The distance from the Rhino Camp location to the treehouse (A) is $1.2 \mathrm{~km}$, and then to the treehouse (B) is $1.8 \mathrm{~km}$. Meanwhile, the distance from the Rhino Camp location to the $R$. arnoldii location (Block A) is $1.8 \mathrm{~km}$; (Block B) $1.9 \mathrm{~km}$; and (Block C, F, E) is $2 \mathrm{~km}$. The distance from Rhino Camp to a small waterfall is around $2.1 \mathrm{~km}$. The closer the distance visitors travel to a tourist attraction, the easier it will be for visitors to come to the location.

According to Mr. Didik Purwanto as a manager of KPH Kotagung Utara, Izin Usaha Pemanfaatan Alam (IUPA) in the KPHL Kotaagung Utara is carried out through the Hutan Kemasyarakatan (HKm). There are 7 Gabungan Kelompok Tani Hutan (Gapoktan) in KPHL Kotaagung Utara, one of which is the 'Gapoktan Lestari Sejahtera'. The Sejahtera Lestari's Gapoktan is chaired by Mr. Rendy Hasaruddin, and this group has been operating for a long time with Government Regulation Number: SK.10098/MENLHK-PSKL/PKPS/PSL.0/12/2019. This is in accordance with the Tanggamus Regency Spatial Plan, namely the realization of an advanced, sustainable, and independent based on the potential of natural resources, without damaging the ecological aspect.

This study found that the appropriate time for tourists who want to see wild elephants in KPH Kotaagung Utara is around 7:30 to $12: 00$ am and 3:00 to 6:00 pm, with each session lasting 3 hours per day. During the day, the elephants will stop feeding due to the hot weather. If the weather is scorching, the Sumatran elephants will seek shade to cool down the body temperature. However, there is a better visual in the day than at night, which is why tourists want to see wild elephants in the daytime. But, if tourists want to see wild elephant's activity at night, they can use binoculars with infrared sensors. Binoculars with an infrared sensor can assist travelers in seeing in the dark and foggy. Elephants are land mammals active at night (nocturnal), from 1:00 pm to 4:00 am. According to Gravett et al. (2017), elephants can sleep in standing or lie down. One of the reasons elephants are not active during the day is because elephants have lousy eyesight. The strong daylight will cause a glare effect for the elephants. 


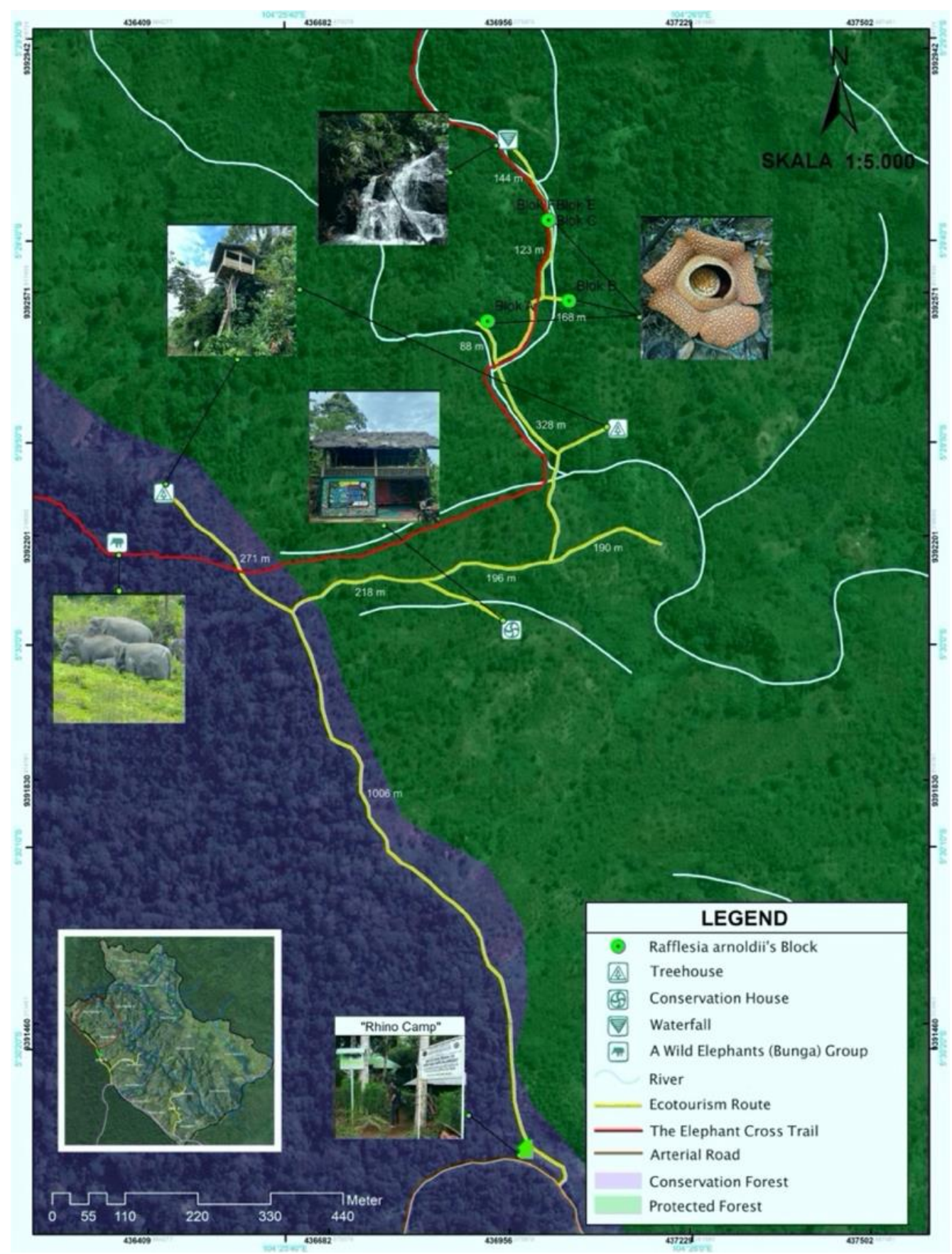

Figure 6. Tourism Maps in Block Lindung II, Register 31, Pematang Arahan, KPH Kotaagung Utara, Tanggamus Regency, Lampung Province, Indonesia

Safety factors practiced when observing wild elephants in KPH Kotaagung Utara include an evacuation route, the use of binoculars, and Personal Protective Equipment (PPE). In an emergency, tourists can leave the treehouses using a rope ladder and follow the existing evacuation route. The evacuation route connects one area to a safe area and meets feasible building requirements to deal with the dangerous emergency response (Rahman and Sinaga 2019). The use of binoculars provides several advantages for tourists, including visual acuity, contrast sensitivity, and a clearer vision than monocular/direct vision (Kumagai et al.
2020). Thus, it facilitates for tourists to see the object. The use of PPE has a vital role in maintaining the safety and security of tourists in observing wild elephants. An accident can create a big issue (lousy reputation) for tourist destinations if an accident occurs during observation. Forestry work has significant risks and these losses can cause fatalities, so the use of PPE is necessary (Nkomo et al. 2018). Despite using PPE, technical prevention is the most important. Therefore, the main benefit of using PPE is avoiding and reducing accidents or health issues for tourists. 


\section{ACKNOWLEDGEMENTS}

The author would like to thank the KPH Kotaagung Utara, Lampung, Indonesia for allowing and assisting in data collection and all who have been involved in the preparation of this study. This study was funded by the World Wide Fund for Nature Indonesia Southern Sumatra Program.

\section{REFERENCES}

Alpiadi A, Erianto, Prayogo H. 2019. Perilaku harian gajah sumatera (Elephas maximus sumatranus) di Elephant Resort Unit Taman Nasional Way Kambas Lampung. J Hutan Lestari 7: 629-638. DOI: 10.26418/jhl.v7i1.32749. [Indonesian]

Amenu BT. 2018. Review: Forest management and conservation practices in Ethiopia: Opportunities and constraints.Asian J For 2: 77-82. DOI: 10.13057/asianjfor/r010204.

Arida INS, Wiguna PPK, Narka IW, Febrianti NKO. 2017. Development planning of tourist village using participatory mapping (Case study: Mambal Village, Badung Regency, Indonesia). IOP Conf Ser Earth Environ Sci 98: 1-11. DOI: 10.1088/1755-1315/98/1/012044.

Bahar A, Kasim NHA, Hambali K. 2018. Home range and movement patterns of Asian elephant (Elephas maximus) in Gua Musang, Kelantan, Malaysia. Malay Nat J 70: 221-232

Basappanavar CH. 2021 Elephant-The Lady Boss-Ecology and Management. Notion Press, Tamil Nadu, South India.

Berliani K, Alikodra HS, Masyud B, Kusrini MD. 2018. Food preference of Sumatran elephant (Elephas maximus sumatranus) to commodity crops in human-elephant conflict area of Aceh, Indonesia. J Phys Conf Ser 1116: 1-10. DOI: 10.1088/1742-6596/1116/5/052015.

Capucchio MT, Colombino E, Tarantola M, Biagini D, Alborali LG, Maisano AM, Scali F, Raspa F, Valle E, Biasato I, Schiavone A, Salogni C, Bar V, Gili C, Guarda F. 2019. The disturbed habitat and its effects on the animal population. IntechOpen J 2019: 1-20. DOI: 10.5772/intechopen.84872.

Cerar J, Nell PC, Reiche BS. 2017. The declining share of primary data and the neglect of the individual level in international business research. J Int Bus Stud 52: 1365-1374. DOI: 10.1057/s41267-02100451-0.

Clegg BW, O'Connor TG. 2017. Determinants of seasonal changes in availability of food patches for elephants (Loxodonta africana) in a semi-arid African savanna. PeerJ 5: 1-13. DOI: 10.7717/peerj.3453.

Collins NJ. 2018. Sumatran Elephant (Elephas maximus sumatranus) Density and Habitat Use in Relation to Forest Characteristics in The Leuser Ecosystem, North Sumatra. [Thesis]. Bournemouth University, Bournemouth. [UK]

Dormann CF, Bagnara M, Boch S, Hinderling J, Otero AJ, Schafer D, Schall P, Hartig F. 2020. Plant species richness increases with light availability, but not variability, in temperate forest understorey. BMC Ecol 20: 1-9. DOI: 10.1186/s12898-020-00311-9.

Evans K. 2019. Bull Elephants, Their Importance as Individuals in Elephant Societies. Decoding Science, Africa Geographic. https://africageographic.com/stories/bull-elephants-their-importanceas-individuals-in-elephant-societies/

Fauvelle C, Diepstraten R, Jessen T. 2017. Meta-analysis of home range studies in the context of trophic levels: Implications for policy-based conservation. PLoS One 12 (3): 1-12. DOI: 10.1371/journal.pone.0173361.

Febryano IG, Rusita. 2018. Perilaku gajah sumatera (Elephas maximus sumatranus) dalam pengembangan wisata pendidikan berbasis konservasi. J Pengelolaan Sumbardaya Alam dan Lingkungan 8: 1-9. DOI: 10.29244/jps1.8.3.376-382. [Indonesian]

Flower EK, Burns GL, Jones DN, McBroom J. 2021. Does the experience make different? Comparing tourist attitudes pre- and post-visit towards the elephant tourism industry. Ann Tour Res Empirical Insights 2: 1-9. DOI: 10.1016/j.annale.2021.100025.

Gravett N, Bhagwandin A, Sutcliffe R, Landen K, Chase MJ, Lyamin OI, Siegel JM, Manger PR. 2017. Inactivity sleep in two wild free roaming African elephant matriarchs - Does large body size make elephants the shortest mammalian sleepers? PLoS One 12 (3): 1-33 DOI: 10.1371 /journal.pone.0171903

Kirom NR, Sudarmiatin, Putra IWJA. 2018. The influence of tourist attractions towards the tourists' satisfaction. KnE Soc Sci 3 (3): 270288. DOI: 10.18502/kss.v3i3.1889.

Koranti K, Sriyanto, Yunanto M. 2018. The development of tourism facilities based on visitor preferences in tourist object Kali Pancur. International Conference of Business, Accounting and Economy Promoting Research and Developmental Activities in Business, Accounting, and Economics Through Social Science Innovations. Universitas Muhammadiyah Purwokerto, Purwokerto, 3-4 August 2018. http://digital.library.ump.ac.id/id/eprint/152. [Indonesian]

Kumagai T, Shoji T, Yoshikawa Y, Mine I, Kanno J, Ishii H, Saito A, Ishikawa S, Kimura I, Shinoda K. 2020. Comparison of central visual sensitivity between monocular and binocular testing in advanced glaucoma patients using imo perimetry. Br J Ophthalmol 11: 1-12. DOI: $10.1136 /$ bjophthalmol-2019-315251.

Kuncoro P, Rosa E, Rustiati EL, Candra D. 2017. Dentifikasi ektoparasit pada gajah sumatera (Elephas maximus-sumatranus) di Pusat Latihan Gajah Taman Nasional Way Kambas. J Biologi Eksperimen dan Keanekaragaman Hayati 4: 51-54. DOI: 10.23960/jbekh.v4i2.134. [Indonesian]

Kurniadu A, Syarifah, Saputra A, Mahanani AI. 2020. Studi perilaku harian gajah sumatera (Elephas maximus sumatranus) di Pusat Konservasi Gajah (PKG) Padang Sugihan. Prosiding Seminar Nasional Sains dan Teknologi Terapan 3: 481-489. [Indonesian]

Kusumaningrum DA, Wachyuni SS. 2020. The shifting trends in travelling after the Covid-19 Pandemic. Intl J Tour Hosp Rev 7 (2): 31-40. DOI: 10.18510/ijthr.2020.724.

Larisha C, Herdiana I, Gunaryadi D, Elfidasari D. 2016. Perilaku dan pola asuh induk (parental care) terhadap anak gajah sumatera (Elephas maximus sumatranus) di Taman Margasatwa Ragunan. J Al-Azhar Indonesia Seri Sains dan Teknologi 3: 196-203. DOI: 10.36722/sst.v3i4.234. [Indonesian]

Lester JN, Cho Y, Lochmiller CR. 2020. Learning to do qualitative data analysis: A starting point. Hum Resour Dev Rev 19: 94-106. DOI: 10.1177/1534484320903890.

Lo YC, Janta P. 2021. Balancing commercialization and sustainability in community-based tourism practices - A qualitative study of factor affecting elephant habitat communities in Nouthern Thailand. Front Psychol 12: 1-8. DOI: 10.3389/fpsyg.2021.685426.

Maryone R. 2015. Rumah Pohon Suku Momuna Yahukimo. J Papua 7 (2): 85-96. DOI: 10.24832/papua.v7i2.20. [Indonesian]

Matthews A, Ruyky L, Ellis B, Gibbon SF, Lunney D, Crowther MS, Glen AS, Purcell B, Moseby K, Stott J, Fletcher D, Wimpenny C, Allen BL, Bommel LV, Roberts M, Davies N, Green K, Newsome T, Ballard G, Fleming P, Dickman CR, Eberhart A, Troy S, McMahon C, Wiggins N. 2013. The success of GPS Collar deployments on mammals in Australia. Aust Mammal 35: 65-83. DOI: $10.1071 /$ AM12021.

Miftahudin, Winarno GD, Santoso T, Darmawan A. 2021. Analisis Obyek Daya Tarik Wisata (ODTW) dan interpretasi jalur ekowisata Elephant Tour di pusat Latihan Gajah Taman Nasional Way Kambas. J Hutan Tropis 9: 270-281. DOI: 10.20527/jht.v9i2.11275. [Indonesian]

Mills EC, Poulsen JR, Fay M, Morkel P, Ciark CJ, Meier A, Beirne C, White LJT. 2018. Forest elephant movement and habitat use in a tropical forest-grassland mosaic in Gabon. PLoS One 13 (7): 1-17 DOI: 10.1371/journal.pone.0199387.

Moßbrucker AM, Fleming CH, Imron MA, Pudyatmoko S, Sumardi. 2016. AKDEc home range size and habitat selection of Sumatran elephants. Wildlife Res 43: 566-575. DOI: 10.1071/WR16069.

Mustafa T, Abdullah, Khairil. 2018. Analisis habitat gajah sumatera (Elephas maximus sumatranus) berdasarkan software Smart di Kecamatan Peunaron, Kabupaten Aceh Timur. J Biotik 6: 1-10. DOI: 10.22373/biotik.v6i1.4041. [Indonesian]

Nkomo H, Niranjan I, Reddy P. 2018. Effectiveness of health and safety training in reducing occupational injuries among harvesting forestry contractors in KwaZulu-Natal. Workplace Health Saf 66: 499-507. DOI: $10.1177 / 2165079918774367$.

Ndlovu M, Rodriguez AP, Devereux E, Thomas M, Colina A, Molaba L. 2018. Water for African elephants (Loxodonta africana); faecal microbial loads affect use of artifical waterholes. Biol Lett 14: 1-5. DOI: $10.1098 / \mathrm{rsbl} .2018 .0360$.

Posta B. 2011. The Effects of Housing and Enrichment on Zoo Elephant Behavior. [Dissertation]. Bowling Green State University, Ohio. [United State]. 
Qomariah IN, Rahmi T, Said Z, Wijaya A. 2019. Condlict between human and wild Sumatran elephant (Elephas maximus sumatranus) in Aceh Province, Indonesia. Biodiversitas 20: 77-84. DOI: 10.13057/biodiv/d200110.

Rahman NV, Sinaga LA. 2019. Analysis of the evacuation route effectiveness based on the hotel's visitor evacuation speed (Case study: Grand Kanaya Hotel, Medan). Intl J Archit and Urban 3: 283297. DOI: 10.32734/ijau.v3i3.3743.

Rizwar, Darmi, Wansir D, Mardianti D. 2017. Ecto and endoparasites on sumatra elephant population at Seblat Elephant Training Center, Bengkulu Province, Indonesia. J Adv Zool 38 (2): 178-185.

Rossello J, Becken S, Gallego MS. 2020. The effects of natural disasters on international tourism: A global analysis. Tour Manag 79: 1-12. DOI: 10.1016/j.tourman.2020.104080.

Saat M, Thamrin, Sudjianto, Yoswati D. 2015. Ecotourism development: Educational media of environmental care. Al-Ta'alim J 22: 129-141. DOI: $10.15548 /$ jt.v22i2.131.

Sach F, Dierenfeld ES, Evans SCL, Watts MJ, Yon L. 2019. African savanna elephants (Loxodonta africana) as an example of a herbivore making movement choices based on nutritional needs. PeerJ 7: 1-27. DOI: $10.7717 /$ peerj.6260.

Sari DP, Suwarno, Saputra A, Marjono. 2016. Studi perilaku monyet ekor panjang (Macaca fascicularis) di Taman Wisata Alam Grojogan Sewu Tawangmangu Karanganyar. Seminar Nasional Konservasi dan Pemanfaatan Sumber Daya Alam 1 (1): 184-187. [Indonesian]

Singh R. 2019. Potential Roles of Tree Leaves in Ruminant Nutrition. Pashudhan Praharee, India.

Sitienei AJ, Jiwen G, Ngene SM, Paix MJDL, Waweru FK. 2012. Analysis in the concentration, determination and comparison of some mineral elements in the Natural Salt-Licks Utilized by Elephants: Mt Elgon National Park Case Study. Open J Adv Mater Res 2: 356-360. 1796-1800. DOI: 10.4028/www.scientific.net/AMR.356-360.1796.
Sitompul AF, Griffin CR, Rayl ND, Fuller TK. 2013. Spatial and temporal habitat use of an Asian Elephant in Sumatra. Animals 3: 670-679. DOI: 10.3390/ani3030670.

Songer M, Sampson C, Williams C, Forrest J, Gyeltshen K, Huy K, Sharma A, Gopala A, Budiman, Sadikin H et al. 2012. Mapping habitat and deforestation in WWF Elephant Priority Landscapes. Gajah: Journal of the Asian Elephant Specialist Group 36: 1-77.

Sugiyanto EEL, Erianto, Prayogo H. 2017. Ketersediaan pakan gajah sumatera [Elephas maximus sumatranus (Temminck, 1847)] di Resort Air Hitam Taman Nasional Tesso Nilo Kabupaten Pelalawan Provinsi Riau. J Hutan Lestari 5: 147-155. DOI: 10.26418/jhl.v5i1.18836. [Indonesian]

Sukoco A. 2012. GIS habitat based models spatial analysisto determine the suitability of habitat for elephants. Intl Conf Eng Technol Dev 2012: 103-107.

Sukmantoro YW, Alikodra HS, Kartono AP, Efransjah. 2019. Niche partitioning on Sumatran elephant (Elephas maximus sumatranus) and human in space and resouces in Riau, Indonesia. Biodiversitas 20: 1362-1273. DOI: 10.13057/biodiv/d200528.

Susatya A. 2011. Rafflesia Pesona Bunga Terbesar di Dunia. LIPI Press, Direktorat Kawasan Konservasi dan Bina Hutan Lindung, Kementerian Kehutanan Indonesia, Jakarta. [Indonesian]

Wilson G, Gray RJ, Radinal R, Hasanuddin H, Azmi W, Sayuti A, Muhammad H, Abdullah, Nazamuddin, Sofyan H, Riddle HS, Stremme C, Desai AA. 2021. Between a rock and a hard place: Rugged terrain features and human disturbance affect behaviour and habitat use of Sumatran elephants in Aceh, Sumatra, Indonesia. Biodivers Conserv 30: 597-618. DOI: 10.1007/s10531-020-02105-3.

Yanti NKF, Watiniasih NL, Suaskara IBM. 2017. Perilaku harian anak gajah sumatra (Elephas maximus sumatranus) di Pusat Konservasi Gajah (PKG) Taman Nasional Way Kambas Lampung. J Metamorfosa 4: 164-170. DOI: 10.24843/METAMORFOSA.2017.v04.i02.p05. [Indonesian] 